\title{
PRESENT STATE OF KNOWLEDGE ON THE FAMILY BEGONIACEAE CA AGARDH (MAGNOLIOPSIDA) OF BANGLADESH
}

\author{
Deb, P. K. and M. A. Rahman ${ }^{1}$ \\ Department of Botany, Gachhbaria Govt. College, Chandanaish, Chittagong, Bangladesh; ${ }^{1}$ Department \\ of Botany, University of Chittagong, Chittagong 4331, Bangladesh
}

\begin{abstract}
The inventory and assessment of species diversity in the mono-generic family Begoniaceae C. A. Agardh of Bangladesh were made through long term field investigations, collections, identification, survey and examination of preserved herbarium specimens and review of relevant taxonomic and floristic literature. The family is recognized to be represented in the flora of Bangladesh by 19 species under the genus Begonia L. Of these, 11 species were known to be previously recorded from the area of Bangladesh, hence additional 8 species of the present account are being reported here for the first time as new records from Bangladesh, these are: Begonia grandis Dryand. ssp. holostylla Irmsch. , B. heracleifolia Cham. and Schltdl. Cult., B. maculata Raddi Cult. B. modestiflora Kurz, B. muliensis T. T. Yu. Cult., B. scintillans Dunn, B. surculigera Kurz and B. thomsonii A. DC. An enumeration of these 19 species is prepared, and each species is cited with detailed taxonomic data. All species of the Begonia L. are herbaceous in nature and possess potential economic values, viz. $11(52 \%)$ medicinal, 5 (24\%) ornamental, $3(14 \%)$ beverage, $1(5 \%)$ food and 1 (5\%) poisonous. Determination of status of occurrence showed that $2(10.53 \%)$ species are common, $5(26.32 \%)$ cultivated, 9 $(47.36 \%)$ threatened and $3(15.79 \%)$ possibly extinct in Bangladesh. Field photographs and hand drawings of recorded taxa are provided.
\end{abstract}

Key words: Begonia, Phenology, Potential value, Conservation status.

\section{INTRODUCTION}

The Begoniaceae, belonging to Magnoliopsida, is a herbaceous family represented by 1,700 species in 68 sections in the fifth largest vascular genus Begonia L. (Frodin 2004) and distributed throughout the tropical and subtropical regions of the world and absent in the Australian tropical forests and the Pacific region from the east of the Fiji to the Galapagos Island (Heywood 2007, Tebbitt 2005). The family has been accounted in the Encyclopedia of Flora and Fauna of Bangladesh with 11 species, including 2 cultivated species, represented in the flora of Bangladesh. The present inventory, based on extensive survey, recognizes the family to be represented in the flora of Bangladesh by 19 species. While examining the preserved herbarium specimens of Begonia L. collected from the flora of Bangladesh we came across the identification of 8 species which have not been recorded previously in any floristic literature. These are: Begonia grandis Dryand. ssp. holostylla Irmsch., B. heracleifolia Cham. and Schltdl. Related to Bangladesh fauna Cult., B. maculata Raddi Cult., B. modestiflora Kurz, B. muliensis T. T. Yu. Cult., B. scintillans Dunn, B. surculigera Kurz and B. thomsonii A. DC. These additional 8 species, including 3 cultivated, are being reported here for the first time as new records for Bangladesh. Detailed data on these new records are provided in the enumeration.

\section{MATERIAL AND METHODS}

The present study on the family Begoniaceae is the part of inventory of the flora conducted under Biodiversity Link Project in the department of Botany of Chittagong University since 1997. The study includes analyzing of previous records, extensive field survey and collection of specimens, identification of collected and preserved herbarium specimens. Relevant floristic literature of Roxburgh (1814, 1824,1832), Hooker (1886-1888), Prain (1903), Heinig (1925), Raizada (1941), Datta and Mitra (1953), Sinclair (1956), Khan and Afza (1968), Khan and Banu (1972), Khan (2001), Khan et al. (1994), 
Rahman and Hassan (1995), Rahman and Uddin (1997), Uddin and Rahman (1999), Rashid et al. (2000), Rahman (1999, 2017), Rasshid and Mia (2001), Khan and Huq (2001), Rahman et al. (2001, 2012), Barbhuiya and Gogoi (2010), Tutul et al. (2010), Uddin and Hassan (2010), Rahman et al. (2010a), Arefin et al. (2011), Rahman et al. (2012, 2013), Rashid and Chowdhury (2013), Rahman et al. (2015), Arefin et al. (2017).

All collected specimens and other unidentified specimens of the family Begoniaceae preserved at Bangladesh National Herbarium (DACB), Dhaka University Salarkhan Herbarium (DUSH) and Herbaria of Chittagong University (HCU), Bangladesh Forest Research Institute (BFRIH), Bangladesh Council for Scientific and Industrial Research (BCSIRH) were critically studied. Status of occurrence of a species is determined following Rahman (2013) and Ara et al. (2013).

\section{RESULTS AND DISCUSSION}

Enumeration of 19 species is prepared with detailed taxonomic data of each species following Rahman (2013). The data includes scientific name, synonym(s), local name(s), phenology, ecology, potential values, places of occurrence in Bangladesh, global distribution, threat to the species, conservation status, conservation measures taken, conservation measures proposed, and with a voucher specimen. Photographs/drawings of newly recorded species are mostly based on herbarium specimens or taken during field investigations.

\section{Enumeration of the taxa}

1. Begonia alicida C. B. Clarke in Hook.f., Fl. Brit. India 2: 637 (1879); Uddin and Hassan (2004); Uddin (2012).

Synonym: Not available. Local name: Not available. Phenology: Fl. \& Fr. June-September.

Ecology: Near water falls, shady-rocky places, 1600-1800 m.

Potential value: Medicinal (Rahman 2013).

Occurrence in Bangladesh: Bandarban (Ruma), Chittagong (Sitakunda), Cox's Bazar (Teknaf) and Rangamati (Kaptai, Shubalong). Global distribution: Myanmar and Thailand.

Threat to the species: Habitat destruction, shifting cultivation, over exploitation of forest resources, burning of jungles etc.

Conservation status: It occurs sporadically near shady rocky places of Bandarban (Ruma), Chittagong (Sitakunda), Cox's Bazar (Teknaf) and Rangamati (Kaptai, Shubalong).

Status of Occurrence: Endangered (EN). [Khatun (2008), Rahman (2013)].

Conservation measures taken: Sporadic in-situ conservation measures have been taken by declaring some Game Reserve, Wildlife sanctuary and Reserve forests.

Conservation measures proposed: Both in-situ and ex-situ methods of conservation have been suggested.

Voucher specimens: 10495 (HCU).

2. Begonia annulata K. Koch, Berliner Allg. Garten. 1: 76 (1837); Wall. Cat. (1828-1849); C. B. Clarke (1879); D. Prain (1903, 1903a); Heinig (1925); Uddin et al. (1998); Uddin (2012).

Synonym: B. barbata Wall. ex A. DC. (1864). Local name: Not available. Phenology: Fl. \& Fr. June to October.

Ecology: In shade near water falls, rocky moist and damp hill slopes, 1300-1800 m.

Potential value: Ornamental, Medicinal, Food and Beverage (Rahman 2013; www. Agroweb.org).

Occurrence in Bangladesh: Bandarban (Ruma), Chittagong (CU Campus), Cox's Bazar (Ukhia), Khagrachari (Matiranga), Moulvi Bazar (Srimongal, Moulvi Bazar), Rangamati (Kaptai, Pablakhali, 
Shubalong, Dhebarmatha) and Sylhet (Samanbag, Jaintapur). Global distribution: Bhutan, India, Myanmar, Nepal and Vietnam.

Threat to the species: Habitat destruction, over exploitation, over exploitation of forest resources, burning of jungles etc.

Conservation status: It occurs in Bandarban, Cox's Bazar, Khagrachari, Moulvi Bazar, Rangamati and Sylhet districts.

Status of occurrence: Common. [Not Evaluated (NE), Khatun 2008; Near threatened (nt), Rahman 2013]

Conservation measures taken: No conservation measures taken.

Conservation measures proposed: Both in-situ and ex-situ conservation is suggested.

Voucher specimens: 10471(HCU).

3. Begonia cathcartii Hook.f. \& Thomson, Him. PI. t. 13 (1855); C.B. Clarke (1879); Datta and Mitra (1953).

Synonyms: Not available. Local name: Not known. Phenology: Fl. \& Fr. May to September.

Ecology: Hill slopes and foot of hills, 900-2000 m.

Potential value: Medicinal or ethnobotanical uses of this species are not yet known.

Occurrence in Bangladesh: Dhaka (Ink.). Global distribution: Bhutan, India, Myanmar, Nepal, Sikkim and Thailand.

Threat to the species: Habitat destruction, shifting cultivation, over exploitation of forest resources etc.

Conservation status: It was recorded by Datta and Mitra (1953) from Dhaka (lnc.) since then no collection or published report is available from elsewhere in Bangladesh.

Status of occurrence: Possibly Extinct from (EX) Bangladesh rr. territory.

Conservation measures taken: No conservation measures taken.

Conservation measures proposed: The plant is to be traced in its collection locality for in-situ or ex-situ conservation management as appropriate.

Notes: The species is Native to Eastern Himalaya and first collected from Sikkim by J. D. Hooker. The species shows an eastern extension up to Myanmar on natural distribution. This species is being reported here according to Datta and Mitra (1953). The species is similar to Begonia annulata K. Koch, but can be nature of distinguished by the presence of dense deflexed hairs on the stem and peduncles, glabrous stipule and leaves on ventral side.

No herbarium specimen is available at DACB, BFRIH, BCSIRH, DUSH and HCU.

4. Begonia cordifolia (Wight) Thwaites, Enum. Pl. Zeyl.: 129 (1859); Uddin et al. (1998).

Synonyms: Begonia arnotiana A. DC. (1864); Diploclinium arnotianum Wight (1815); D. cordifolium Wight (1816). Local Name: Not known. Phenology: Fl. \& Fr. January to September.

Ecology: Shady moist-rocky places, $800-1600 \mathrm{~m}$.

Potential value: Not known.

Occurrence in Bangladesh: Rangamati (Sitapahar). Global distribution: India, Sri Lanka.

Threat to the species: Habitat destruction, over exploitation of forest resources, burning of jungles etc.

Conservation status: It was recorded by Uddin and Hassan (1998) from Rangamati, theteafter no report of collection is available. It could not be relocated in its collection locality.

Status of occurrence: Data Deficient (DD).

Conservation measures taken: No conservation measures taken.

Conservation measures proposed: The plant is to be traced in its collection locality for in-situ or ex-situ conservation management as appropriate. 


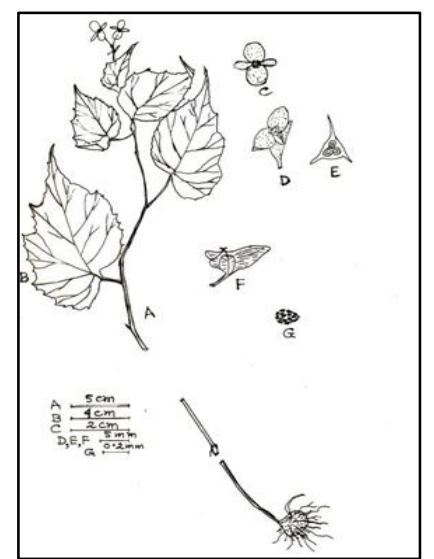

a

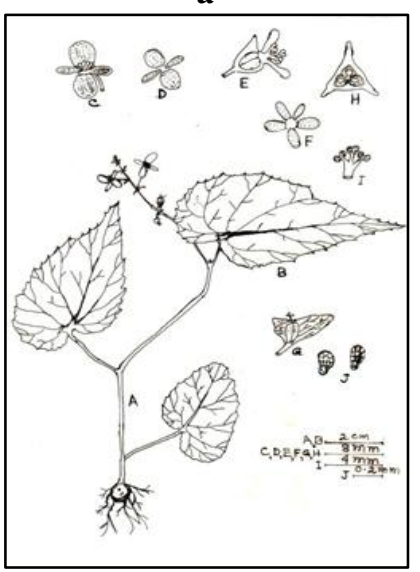

$\mathbf{e}$

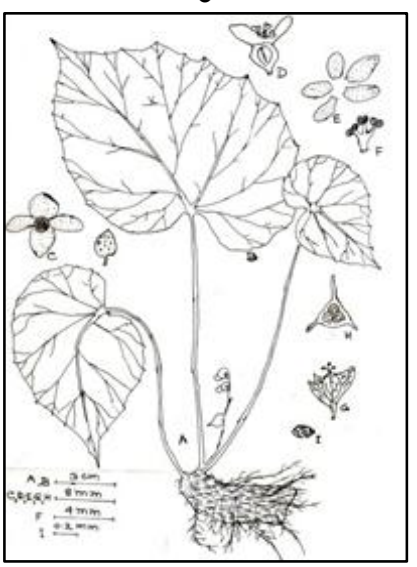

i

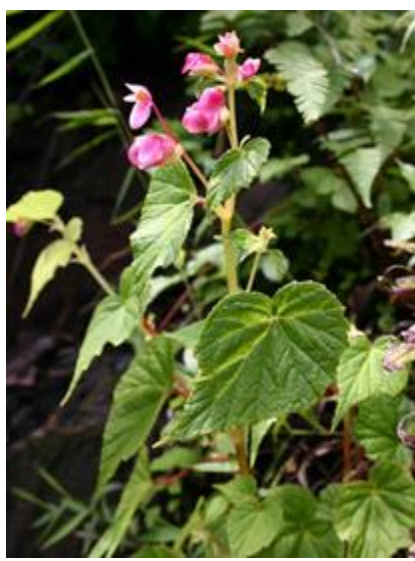

b

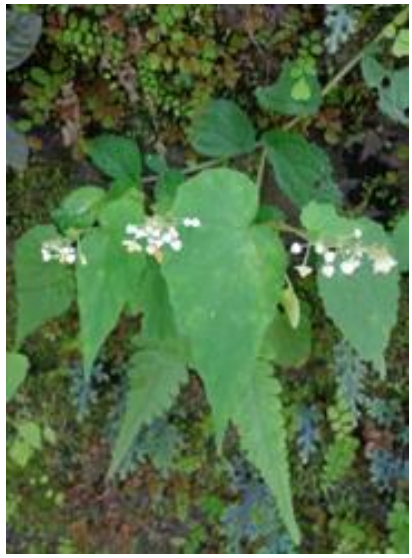

f

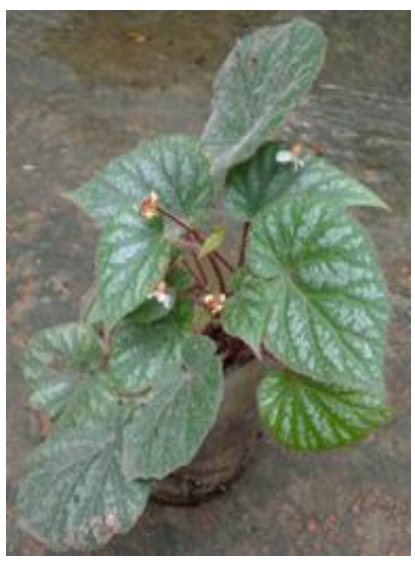

j

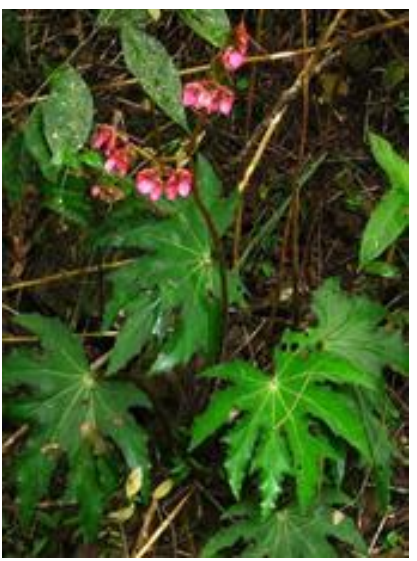

c

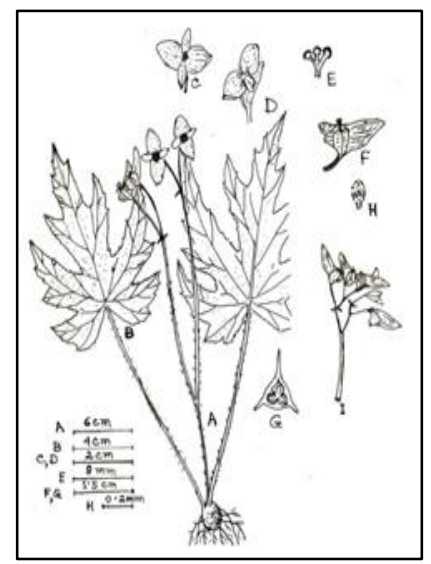

$\mathbf{g}$

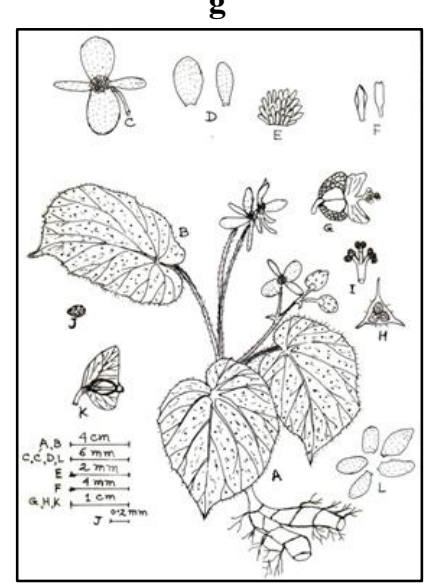

$\mathbf{k}$

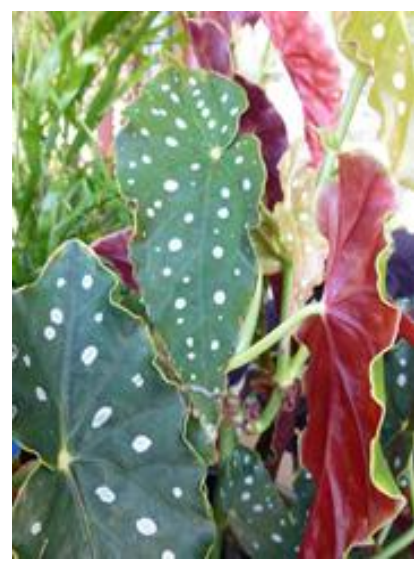

d

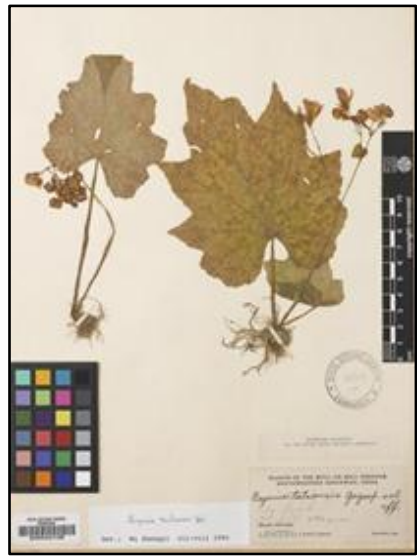

$\mathbf{h}$

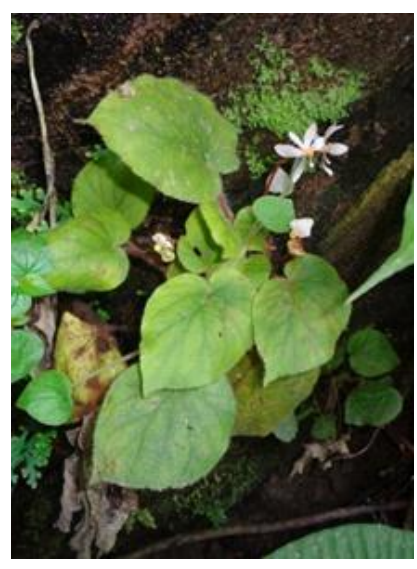

1

Fig. 1. Pictorial presentation of new records of examined plants: a. and b. Begonia grandis Dryand. ssp. holostylla Irmsch; c. Begonia heracleifolia Cham. and Schltdl; d. Begonia maculata Raddi; e. and f. Begonia modestiflora Kurz; g. and h. Begonia muliensis T. T. Yu; i. and j. Begonia scintillans Dunn; k. and l. Begonia thomsonii A. DC.

5. Begonia cucullata Willd., Sp. Pl., 4: 414 (1805).

Synonyms: B. semperflorens Link and Otto(1829) English name: Wax Begonia, Red Pearl Begonia, White comet, Free Flowering Begonia. Local name: Lalmukta Begonia, Shada Begonia. Phenology: Fl. \& Fr. almost throughout the year. 
Ecology: Extremely rare in natural habitats, found occasionally on rocky crevices; $800-1500 \mathrm{~m}$. In Bangladesh it is planted as an ornamental plant as a pot herb.

Potential value: Ornamental and Medicinal (Barceloux 2008).

Occurrence in Bangladesh: Dhaka (Cult. in Mirpur Botanical Garden). Cultivation in a single place (agerden od elsewhere) needs conservation care as at any time it may be vanished.

Global distribution: America, Argentina, Brazil, India, Taiwan, Paraguay and Uruguay.

Threat to the species: At present no threat.

Conservation status: It was collected from Dhaka by Mahbuba, Rezia and Hosne Ara from cultivation.

Status of occurrence: Cultivated. [Least Concern (lc.)]. EX- indicates it is Extinct (EX) from the world.

Conservation measures taken: Not required.

Conservation measures proposed: As it is cultivated, no conservation measure is suggested.

6. Begonia grandis Dryand. ssp. holostyla Irmsch., Mitt. Inst. Allg. Bot. Hamburg 10: 498, pl.14, 15 (1939). Fig. 1a and b.

Synonyms: Not available. Local name: Not known. Phenology: Fl. \& Fr. March to October.

Ecology: Streams in dense forest valleys, moist rocky cliffs of valleys, wet fissures of limestone rocks, on rocks in shaded moist environments, on slopes, in valleys, or by streams; $2200-2800 \mathrm{~m}$.

Potential value: Folk medicine and Beverage. (www.Agroweb.org)

Occurrence in Bangladesh: Chittagong (Chunati). Global distribution: China, India, Indonesia, Thailand and Myanmar.

Threat to the species: Habitat destuction, over exploitation of forest resources, burnings of jungles etc.

Conservation status: One collection of it has been made from Chittagong, Lohagara, Chunati Wild-life Sanctuary.

Status of occurrence: Critically Endangered (CR).

Conservation measures taken: No conservation measures yet taken.

Conservation measures proposed: Both in-situ and ex-situ conservation measures is suggested.

Voucer specimen: Rahman and Dev s.n. (HCU).

7. Begonia heracleifolia Cham. and Schltdl., Linnea, 5: 603 (1830). Fig. 1c.

Synonym: Not available. Local name: Not known. Phenology: Fl. \& Fr. March to September.

Ecology: Scattered in the underneath of primary forests; $130-1700 \mathrm{~m}$.

Potential value: Ornamental and Medicinal. (Alonso-Castro et al. 2011; Barceloux 2008)

Occurrence in Bangladesh: Dhaka (Cult. in Ramna Park). Global distribution: America, Belice, El Salvador, Guatemala, Honduras, India, Mexico, Panama, Taiwan.

Threat to the species: Presently as it is a cultivated plant, it has no threat. May be Extinct (EX) from Bangladesh territory.

Conservation status: Dhaka in cultivated condition.

Status of occurrence: Cultivated.

Conservation measures taken: Cultivated.

Conservation measures proposed: Not required.

8. Begonia maculata Raddi, Alc. Sp. Rett. Piat. Bras. 406 (1820). Fig. 1d.

Synonym: Begonia corallina Carr. (1875). Local Name: Not known. Phenology: Fl. \& Fr. January to September.

Ecology: Extremly rare in natural habitats, found occasionally on rocky crevices; 800-1800 m. In Bangladesh it is planted as an ornamental plant as a pot herb. 
Potential value: Ornamental.

Occurrence in Bangladesh: Dhaka (Cult. in Ramna Park). Cultivation in a single place (agerden or elsewhere) needs conservation care as at any time it may be vanished. May be Extinct (EX) from Bangladesh territory.

Global distribution: America, Brazil to Argentina.

Threat to the species: Presently no threat.

Conservation status: Dhaka in garden.

Status of occurrence: Cultivated.

Conservation measures taken: Cultivated.

Conservation measures proposed: Not required.

9. Begonia megaptera A. DC., Ann. Sci. Nat. Ser. 4, 11: 134 (1859); Wall. Cat. (1828-1849); C. B. Clarke (1879).

Synonym: Begonia malabarica Wall. (1831). Local name: Not available. Phenology: Fl. \& Fr. August to December.

Ecology: Extremely rare in natural habitats, found occasionally on rocky crevices; $500-1800 \mathrm{~m}$. In Bangladesh it is planted as an ornamental plant as a pot herb.

Potential value: Ornamental and medicinal. (Rajbhandary 2013)

Occurrence in Bangladesh: Dhaka (Cult.). Cultivation in a single place (agerden or elsewhere) needs conservation care as at any time it may be vanished.

Global distribution: Bhutan, W. China, India, Myanmar and Nepal.

Threat to the species: Habitat destruction, unscientific shifting cultivation, over exploitation of forest resources, burning of jungles etc.

Conservation status: Dhaka (lnk.). May be Extinct (EX) from Bangladesh territory.

Status of occurrence: Extinct (EX). [Endangered (EN), Afroz 2008].

Conservation measures taken: No conservation measures taken.

Conservation measures proposed: The plant is to be located to its reported sites and both in-situ and exsitu conservation measures to be taken as appropriate.

Note: No herbarium specimen is available at DACB, BFRIH, BCSIRH, DUSH and HCU. This species has been reported here according to Afroz 2008.

10. Begonia modestiflora Kurz, Flora 54: 296 (1871). Fig. 1e and f.

Synonym: Not available. Local name: Not known. Phenology: Fl. \& Fr. August to November.

Ecology: Forests margins, shaded moist rocky slopes environments by streams; 500-2200 m.

Potential value: Medicinal. (Hossain et al. 2005)

Occurrence in Bangladesh: Khagrachari (Matiranga: Alotila). Global distribution: China to Indo-China, India, Laos, Myanmar, Nepal and Thailand.

Threat to the species: Habitat destruction, unscientific shifting cultivation, over exploitation of forest resources, burning of jungles etc.

Conservation status: One collection of it has been made from Alutilla under Khagrachari district.

Status of occurrence: Endangered (EN).

Conservation measures taken: No conservation measures taken.

Conservation measures proposed: The plant is to be conserved to its reported sites and both in-situ and ex-situ conservation measures to be taken as appropriate.

Voucher specimen: 10473 (HCU). 
11. Begonia muliensis T.T. Yu, Bull. Fam. Mem. Inst. Biol., n.s., 1: 119 (1948). Fig. 1g and h Synonym: Not available. Local Name: Not known. Phenology: Fl. \& Fr. February to September. Ecology: Forests rocks in moist environments; $1800-2600 \mathrm{~m}$.

Potential value: Ornamental.

Occurrence in Bangladesh: Dhaka (Cult. in DU Bot. Gard.). Global distribution: China. EX- indicates it is Extinct (EX) from the world.

Threat to the species: Presently no threat.

Conservation status: Dhaka (DU botanical garden).

Status of occurrence: Cultivated.

Conservation measures taken: Cultivated

Conservation measures proposed: Not required.

12. Begonia palmata D. Don, Prodr. Fl. Nepal 223 (1825); Heinig (1925); C. B. Clarke (1879); Khatun and Afroz (2008).

Synonyms: Begonia laciniata Roxb. (1832); B. bowringians Champ. (1825); B. laciniata Roxb. ex Wall. (1831). English name: Beefsteak Geraniums, Elephants Ear. Phenology: Fl. \& Fr. June to December.

Ecology: In evergreen forests moist rocky hill slopes; 1500-2400 m.

Potential value: Medicinal, Food \& Beverage.

Occurrence in Bangladesh: Rangamati (lnk.) and Sylhet (lnk.). Global distribution: Bhutan, China, India, Indonesia, Indo-china, Laos, Myanmar, Nepal, Taiwan, Thailand \& Vietnam.

Threat to the species: Habitat destruction, unscientific shifting cultivation, over exploitation, over exploitation of forest resources, burning of jungles etc.

Conservation status: It was collected from Chittagong and Hill Tracts by Heinig (1925) and since then it has not been collected from any other place of Bangladesh.

Status of Occurrence: May be Extinct (EX) from Bangladesh territory. [Not Evaluated (NE) Extinct (EX) (Rahman 2013)]

Conservation measures taken: No conservation measures yet been taken.

Conservation measures proposed: Relocating its origin, both of in-situ and ex-situ conservation are suggested.

Note: It was first recorded by William Roxburgh (1832) from East Bengal $(\ln c)$ since then no collection or report is available. No herbarium specimen is available at DACB, BFRIH, BCSIRH, DUSH and HCU.

13. Begonia rex Putz. Fl. Des. Serr. 2141 t. 1255, 1256 (1857); C.B. (1879); Khatun and Afroz (2008); Uddin (2012).

Synonym: Not available. English name: White comet, Merry Christmas, Salamonder, President Begonia. Local name: Christmas Begonia, Lalmukta Begonia. Phenology: Fl. \& Fr. almost all the year round.

Ecology: Scattered in the moist dark places, under shrubs, $200-900 \mathrm{~m}$.

Potential value: Medicinal, Ornamental.

Occurrence in Bangladesh: Chittagong \& Dhaka (Cult. in NBG), Rangamati (Sitapahar, Uddin 2012).

Global distribution: China, India, Nepal, Myanmar,Taiwan and Vietnam.

Threat to the species: At present no threat.

Conservation status: Dhaka (Mirpur botanical garden).

Status of occurrence: Cultivated. [Least Concern (lc)]

Conservation measures taken: Cultivated.

Conservation measures proposed: Not required.

Voucher specimen: R451 (DACB). 
14. Begonia roxburghii (Miq.)A. DC., Prodr. 15 (1): 398 (1864); C.B. Clarke (1879); Kanjilal et al. (1938); Uddin et al. (1998); Uddin et al. (2003); Uddin (2010); Uddin (2012); Uddin et al. (2013a, 2013b).

Synonyms: Begonia malabarica Roxb. (1832); Diploclinium roxburghii Miq. (1856); Casparya oligocarpa A. DC.(1859); C. polycarpa A. DC. (1859). Local name:Not available. Phenology: Fl. \& Fr. June to August.

Ecology: Forest margins and foot of hill, moist and shady areas; $600-1200 \mathrm{~m}$.

Potential value: Ornamental \& Food; Medicinal (Rahman 2012).

Occurrence in Bangladesh: Bandarban (Ruma), Chittagong (Hazarikhil, Dohazari) Cox's Bazar (Himchari, Teknaf), Moulvi Bazar (Srimongal), Rangamati (Naniarchar, Kaptai, Jurachari) \& Sylhet (Jaintapur, Kurma beat). Global distribution: Bhutan, China, India, Indonesia, Myanmar and Nepal.

Threat to the species: Habitat destruction, over exploitation, over exploitation of forest resources, burning of jungles etc.

Conservation status: Several places of Bandarban, Chittagong, Cox's Bazar, Khagrachari, Moulvi Bazar, Rangamati and Sylhet.

Status of occurrence: Common. [Not Evaluated (NE)]

Conservation measures taken: No conservation measures taken.

Conservation measures proposed: Both in-situ and ex-situ conservation measures to be taken as appropriate.

Voucher specimen: 10500 (HCU).

15. Begonia rubella Buch.-Ham. ex D. Don, Prodr. Fl. Nepal : 223 (1825); A. DC.(1864); C.B. Clarke (1879); Uddin (2012); Uddin and Hassan (2010).

Synonym: Begonia scutata Wall. Cat. 3687 (1831). Local name: Not known. Phenology: Fl. \& Fr. July to December.

Ecology: Grows in shady, moist hill slopes in evergreen forests, 600-1700 m.

Potential value: Medicinal, Food and Hair dye (Hossain et al. 2005; Rajbhandary 2013)

Occurrence in Bangladesh: Rangamati (Sitapahar, Kaptai). Global distribution: Bhutan, India, Nepal, Sikkim and Myanmar.

Threat to the species: Habitat destruction, unscientific shifting cultivation, over exploitation of forest resources, burning of jungles etc.

Conservation status: Rangamati (Kaptai Sitapahar).

Status of occurrence: Critically Endangered (CR).

Conservation measures taken: No conservation measures taken.

Conservation measures proposed: It is to be located for conservation management either both in-situ and ex-situ or as appropriate.

Voucher specimen: N-2650 (DACB).

Note: I have not been able to collect this species from reported locality.

16. Begonia scintillans Dunn in Kew Bull. 1920: 111 (1920). Fig. 1i and j.

Synonyms: Not available. Local Name: Not known. Phenology: Fl. \& Fr. Octobar to March.

Ecology: Moist hill slopes or foot of the hill; 500-2000 m.

Potential value: Medicinal or ethnobotanical uses of this species is not yet known.

Occurrence in Bangladesh: Rangamati (Kaptai) and Sylhet (Samanbagh). Global distribution: China, India, Indonesia, Myanmar and Thailand. 
Threat to the species: Over exploitation, unscientific shifting cultivation, burning of jungles, habitat destruction etc.

Conservation status: Sporadically remaining in Rangamati (Kaptai) and Sylhet (Samanbagh).

Status of occurrence: Critically Endangered (CR).

Conservation measures taken: No conservation measures yet taken.

Conservation measures proposed: Both in-situ and ex-situ conservation measures are suggested.

Vaucer Specimens: 10499 (HCU).

Note: This species is being reported here for the first time in Bangladesh from Rangamati and Sylhet district.

17. Begonia silhetensis (A. DC.) C.B. Clarke in Hook f., Fl. Brit Ind. 2: 636 (1879); Wall. Cat. (1831), Sinclair (1956); Rahman et al. (2012); Uddin (2012).

Synonyms: B. gigantea Wall. (1831) num. nud; Casparya silhetensis DC. (1864). Local name: Not known. Phenology: Fl. \& Fr. January to June.

Ecology: In shady, damp hill slopes near water falls; 800-1500 m.

Potential value: Medicinal and Food (Alam et al. 2006; Uddin 2012).

Occurrence in Bangladesh: Rangamati (Kaptai-Sitapahar \& Rampahar, Belaichari). Global distribution: China, India, Indonesia, Myanmar and Thailand.

Threat to the species: Habitat destruction, unscientific shifting cultivation, over exploitation, over exploitation of forest resources, burning of jungles etc.

Conservation status: The last collection of it has been made from Farua Reserve Forest, Rangamati in 2009 by Bushra et al. The present author collected one unfertile specimen from Adampur reserve forest, Moulvi Bazar.

Status of occurrence: Endangered (EN).

Conservation measures taken: No conservation measures taken.

Conservation measures proposed: Both in-situ and ex-situ conservation measures have been suggested as appropriate.

Voucher specimen: 1084 (HCU).

18. Begonia surculigrera Kurz, Flora 296 (1871). Fig. 1k and 1.

Synonym: Not available. Local name: Not known. Phenology: Fl. \& Fr. June to October.

Ecology: In hill slope shaddy moist rocky places, in evergreen forest, 800-2300 m.

Potential Value: No medicinal or ethnobotanical uses is yet known.

Occurrence in Bangladesh: Cox's Bazar (Teknaf). Global distribution: India and Myanmar.

Threat to the species: Habitat destruction, over exploitation of forest resources, burning of jungles etc.

Conservation status: Only one specimen of this species, collected from Teknaf of Cox's Bazar in 1998, is available at BCSIRH. No specimen could be found yet from elsewhere in Bangladesh.

Status of occurrence: Critically endangered (CR).

Conservation measures taken: No conservation measures yet taken.

Conservation measures proposed: It should be relocated and conserved in-situ or ex-situ as appropriate. Voucher specimen: 1007 (HCU).

Note: This species is being reported here for the first time in Bangladesh from Boroitali, Teknaf, Cox's Bazar district. May be Extinct (EX) from Bangladesh territory.

19. Begonia thomsonii A. DC., in Ann. Sci. Nat. Bol. 4. 11: (1859) and Prodr. (1864); C. B. Clarke (1879); Kanjilal et al. (1938).

Synonym: Not available. Local name: Not known. Phenology: Fl. \& Fr. June to October. 
Ecology: Grows in shady, moist-rocky hill slopes in evergreen forests, 300-1800 m.

Potential value: Medicinal.

Occurrence in Bangladesh: Rangamati (Kaptai Sitapahar \& Rampahar, Jamaichari, Barkal,) and Moulvi Bazar (Srimongal). Global distribution: India, Sikkim and Myanmar.

Threat to the species: Habitat destruction, unscientific shifting cultivation, over exploitation, over exploitation of forest resources, burning of jungles etc.

Conservation status: Rangamai (Kaptai) and Moulvi Bazar (Lawachara).

Status of occurrence: Vulnerable (VU).

Conservation measures taken: No conservation measures yet been taken.

Conservation measures proposed: Both in-situ and ex-situ conservation has been proposed.

Voucher specimens: 10512 (HCU).

\section{REFERENCES}

Afroz, S. 2008. Begoniaceae. In: Ahmed, Z.U., Hassan, M. A., Begum, Z. N. T., Khandker, M., Kabir, S. M. H., Ahmed, M., Ahmed, A.T.A., Rahman, A. K. T. and E. U. Haque (eds.). Encyclopedia of Flora and Fauna of Bangladesh. Vol. 7. Asiatic Society of Bangladesh, Dhaka., pp.7-13.

Alam, M. S., M. A. Hassan and M. Z. Uddin. 2006. A preliminary checklist of the Angiospermic flora of Ghagoti Union under Kapasia Upazilla in Gazipur district, Bangladesh. Bangladesh J. Plant Taxon. 13(2): $155-170$.

Ara, H., B. Khan and S. N. Uddin. 2013. Red Data Book of Vascular Plants of Bangladesh. Bangladesh National Herbarium, Dhaka. 2: 1-180.

Arefin, M. K., M. M. Rahman, M. Z. Uddin and M. A. Hassan.2011. Angiospermic Flora of Satchari National Park, Habiganj, Bangladesh. Bangladesh J. Plant Taxon. 18(2): 117-140.

Arefin, M. S., M. K. Hossain and M. A. Hossain. 2017. Plant diversity of Sonadia island - An ecologically critical area of south-east Bangladesh. Bangladesh J. Plant Taxon. 24(1): 107-116.

Barbhuiya, H. A. and R. Gogoi. 2010. Plant Collection from Bangladesh in the Herbarium at Shillong (ASSAM), India. Bangladesh J. Plant Taxon. 17(2): 141-165.

Cowan, J. M. 1928. The Flora of Chakaria Sundarbans. Calcutta. Rec. Bot. Surv. Ind. 11(2): 197-226.

Datta, R. M. and J. N. Mitra. 1953. Common plants in and around Dacca. Bull. Bot. Soc. Bengal. 7(1 and 2): 25-30.

Frodin, D. G. 2004. History and concepts of big plant genera. Taxon. 53: 753-776.

Heinig, R. L. 1925. List of Plants of the Chittagong Collectorate and Hill tracts. The Bengal Government Press, Darjeeling, India., pp. 55-59.

Heywood, V. H. 2007. Flowering plants families of the world. Firefly Books, Buffalo, N. Y.

Hooker, J. D. 1886-1888. Flora of British India. L. Reeve and Co. Ltd., Kent, England. 5: 1-910

Hossain, M. M., M. A. Hassan and M. S. Uddin. 2005. A Checklist of Angiospermic flora of Lalmai Hills, Comilla, Bangladesh. Bangladesh J. Plant Taxon. 12(2): 85-96.

Kanjilal, U. N., P. C. Kanjilal, A. Das and R. N. De. 1938-1939 (reprint 1982). Flora of Assam. A Von Book Company, Delhi, India. 4: 135-223. 
Khan, M. S. and S. K. Afza. 1968. A taxonomic report on the angiospermic flora of Teknaf and St. Martin's Island. Dhaka Univ. Stud. Part B. 16: 35-37.

Khan, M.S. and F. Banu. 1972. A taxonomic report on the Angiospermic flora of Chittagong Hill Tracts2(Dicotyledines). J. Asiat. Soc. Bengal. 17(2): 59-88.

Khan, M. S. and A. M. Huq. 2001. The vascular flora of Chunati Wildlife Sanctuary in South Chittagong, Bangladesh. Bangladesh J. Plant Taxon. 8(1): 47-64.

Khan, M. S., M. M. Rahman and M. A. Ali. 2001. Red Data Book of Vascular Plants of Bangladesh. Bangladesh National Herbarium, Dhaka.

Khan, M. S., M. A. Rahman, A. M. Huq, M. M. K. Mia and M. A. Hassan.1994. Assessment of Biodiversity of Teknaf Game Reserve in Bangladesh focusing on economically and ecologically important plant species. Bangladesh J. Plant Taxon. 2 (1 and 2): 47-79.

Prain, D. 1903. Bengal Plants. Botanical Survey of India, Bishen Singh Mahendra Pal Singh, Dhera Dun, India. 2: 694-716.

Prain, D.1903a. Flora of the Sundribuns (Sundarbans). Records of the Botanical Survey of India. 114: 312-313.

Rahman, M. A. 1999. Some new angiospermic records for Bangladesh. Biodiversity Newsletter Bangladesh. 3(2): 1.

Rahman, M. A. 2013. Red Data Book of Flowering Plants of Bangladesh. Department of Botany, University of Chittagong, Bangladesh. 1: 1-256.

Rahman, M. A. 2017. Plant diversity in Hazarikhil wildlife sanctuary of Chittagong and its conservation management. J. biodivers. conserve. bioresour. manag. 3(2): 43-56.

Rahman, M. A. and S. B. Uddin. 1997. Assessment of plant diversity of Sitakunda in Chittagong. Bangladesh J. Plant Taxon. 4(1): 17-36.

Rahman, M. A., S. C. Das and M. E. Rashid. 2010a. The IUCN Red List Categories of Angiosperm Plants of Bangladesh and their Conservation. J. Taxon. Biodiv. Res. 4: 17-34.

Rahman, M. A., M. N. Uddin, M. E. Rashid, M. N. Uddin and M. M. Islam. 2012. Floristic Diversity in Rampahar reserve forest of Kaptai, Rangamati. Biod. Bull. 6: 1-31.

Rahman, M. O., R. T. Antara, M. Begum and M. A. Hassan. 2012. Floristic diversity of Dhamrai upazila of Dhaka, Bangladesh with emphasis on medicinal plants. Bangladesh J. Bot. 41(1): 71-85.

Rahman, M. O. and M. A. Hassan. 1995. Angiospermic flora of Bhawal National Park, Gazipur, Bangladesh. Bangladesh J. Plant Taxon. 2(1 and 2): 47-79.

Rahman, M. O., M. Begum and M. W. Ullah. 2013. Angiosperm flora of Sadar Upazilla of Munshigonj District, Bangladesh. Bangladesh J. Plant Taxon. 20(2): 213-231.

Rahman, M. O., M. Z. Uddin, E. Tutul, M. Begum and M. A. Hassan. 2010b. Additions to the Angiospermic flora of Runctia Sal Forest, Bangladesh. Bangladesh J. Plant Taxon. 17(2): 167-181.

Rahman, M. S., G. M. Hossain, S. A. Khan and S. N. Uddin. 2015. An annotated checklist of the vascular plants of Sundarban mangrove forest of Bangladesh. Bangladesh J. Plant Taxon. 22(1): 17-41.

Raizada, M. B. 1941. On the flora of Chittagong. The Indian Forester. 67(5): 253. 
Rajbhandary, S. 2013. Traditional uses of Begonia species (Begoniaceae) in Nepal. J. Nat. Hist. Mus. 27: 25-34.

Rashid, M. H. and M. K Mia. 2001. Angiospermic flora of Madhupur National Park, Bangladesh. Bangladesh J. Plant Taxon. 2(1 and 2): 47-79.

Rashid, M. H. and M. A. I Chowdhury. 2013. Additions to the angiosperm flora in the Sitapahar Reserve Forest of Kaptai, Rangamati, Bangladesh. Bangladesh J. Plant Taxon. 20(2): 255-257.

Rashid, M. H., E. Rahman and M. A. Rahman. 2000. Additions to the Angiospermic flora of the Moheskhali Island, Cox's Bazar, Bangladesh. Bangladesh J. Plant Taxon. 7(1): 43-63.

Roxburgh, W.1814. Hortus Bengalensis (num.nud.). Boerhaave Press, Leiden, Holland. 105 pp.

Roxburgh, W. 1824. Flora Indica. In: Carey, W. and Wallich, N. (eds.). Vol. 2. Mision Press, Serampore, Calcutta, India.

Roxburgh, W. 1832. Flora Indica. In: Carey, W. and Wallich, N. (eds.). Vol. 3. Mision Press, Serampore, Calcutta, India. 875 pp.

Sharma, B. D., N. P. Balakrishnan, R. R. Rao and P. K. Hajra. 1993. Flora of India. Botanical Survey of India, Calcutta. 1: 1-467.

Sinclair, J. 1956. The Flora of Cox’s Bazar, East Pakistan (Bangladesh). Bull. Bot. Soc. Bengal. 9(2): 105-106.

Tebbitt, M. C. 2005. Begonias: Cultivation, identification, and natural history. Timber Press. Portland.

Tutul, E., M. Z. Uddin, M. O. Rahman and A. H. Hassan. 2010. Angiospermic Flora of Runctia Sal Forest, Bangladesh. II. Magnoliopsida (Dicots). Bangladesh J. Plant Taxon. 17(1) 33-53.

Uddin, M. Z. and M. A. Hassan. 2004. Flora of Rema-Kalenga Wildlife Sanctuary. IUCN, Bangladesh Country Office, Dhaka, Bangladesh. 122 pp.

Uddin, M. Z. and M. A. Hassan. 2010. Angiospermic Diversity of Lawachara National Park (Bangladesh): A Preliminary Assessment. Bangladesh J. Plant Taxon. 17(1): 9-22.

Uddin, M. Z., M. F. Alam, M. A. Rahman and M. A. Hassan. 2013a. Diversity in Angiosperm flora of Teknaf Wildlife Sanctuary, Bangladesh. Bangladesh J. Plant Taxon. 20(2): 145-162.

Uddin, M. Z., M. A. Hassan and M. S. Khan. 2003. An Annotated Checklist of angiospermic Flora of Rema-Kalenga Wildlife Sanctuary. (Hobiganj) in Bangladesh. 11a. Magnoliopsida (Dicots). Bangladesh J. Plant Taxon. 10(1): 79-94.

Uddin, S. B. and M. A. Rahman.1999. Angiospermic flora of Himchari National Park, Cox's Bazar. Bangladesh J. Plant Taxon. 6(1): 31-68.

Uddin, S. N. 2012. Floristic Studies on Rampahar and Sitapahar Reserve Forests, Rangamati, Bangladesh. Ph.D. Thesis, Dhaka University.

Uddin, S. N., M. S. Khan, M. A. Hassan and M. K. Alam. 1998. An annotated checklist of angiospermic flora of Sitapahar at Kaptai in Bangladesh. Bangladesh J. Plant Taxon. 5(1): 13-46.

Uddin, M. G., M. E. Rashid and M. A. Rahman. 2013b. Plant diversity in Upper Rezu Reserve forest of Ramu, Cox's Bazar. Biod. Bull. Bangladesh. 7(1): 1-33.

DOI: $\underline{\text { http://dx.doi.org/10.3329/jbcbm.v4i1.37875 }}$ 